\title{
HCV INFECTION FREQUENCY AND TRENDS AMONG VOLUNTARY BLOOD DONORS IN CLUJ COUNTY (ROMANIA) BETWEEN 2006 AND 2011
}

\section{GIORGIANA HÂȚU, IRINA MARIA BRUMBOIU, IOAN STELIAN BOCȘAN}

Epidemiology and Primary Health Care Department, Iuliu Hatieganu University of Medicine and Pharmacy, Cluj-Napoca, Romania

\begin{abstract}
Background and aims. In Europe a wide variation in HCV prevalence between countries was described, ranging from 0.1 to $6.0 \%$, higher in Eastern Europe than in Western Europe, which may threaten the biological safety of donated blood. The HCV frequency among blood donors in Romania has has made the object of only very few published studies.

The aim of this study was to analyze the frequency of anti-HCV antibodies in blood donors from Cluj County (Romania) and its trend, in the period 2006-2011.

Patients and methods. Between 2006-2011 all donors, new and repeat donors were screened for hepatitis $C$ virus infections using enzyme-linked immunosorbent assay (ELISA). Reactive results were confirmed using radioimmunoblotting assay (RIBA). The frequency and trends were analyzed using the T-test and $X^{2}$-test.

Results. There were 95,181 donors tested in the blood transfusion centre (BTC) laboratories between 2006-2011. The overall prevalence was $0.254 \%$ (95\% CI 0.2220.286). The prevalence rates of anti-HCV antibodies increased with age between both genders, being higher among women, starting to decrease after the age of 51.

Conclusions. The results of this study demonstrate a high HCV prevalence in donations from 2006 to 2011, as compared to other countries in Europe, especially among first time blood donors, an infection that might be a potential threat to blood safety
\end{abstract}

Keywords: blood donation, hepatitis C infection, prevalence.

\section{Background \& aims}

Hepatitis $\mathrm{C}$ is nowadays recognized as a disease of global importance, concerning both industrialized and developing countries [1]. Whereas many infections were contracted in the past, $\mathrm{HCV}$ prevalence is the key measure in quantifying the burden of the hepatitis $\mathrm{C}$ problem and guiding health care resources planning. In contrast to the incidence data collected by surveillance systems, the assessment of prevalence requires representative population surveys [2]. The global prevalence of HCV is 3\% with 170-184 million persons infected worldwide [3-6]. The available data from Europe indicate a wide variation in $\mathrm{HCV}$ prevalence between countries, ranging from 0.1 to $6.0 \%$ [7-9]. The prevalence seems to be higher in Eastern

Manuscript received: 21.07 .2014

Recieved in revised form: 01.09.2014

Accepted: 02.09.2014

Address for correspondence: funinganag@yahoo.com
Europe than in Western Europe [8]. Although considerable differences in geographical distribution of these infections in Europe exist, it is doubtful whether the very high frequencies of some countries reflect reliable data sets or, merely, refer only to ELISA screening positive donors (including many false positives), as opposed to 'confirmed positive donors' [10].

Transfusion-associated $\mathrm{HCV}$ infection was a worldwide risk before $\mathrm{HCV}$ testing became available. It has been virtually eliminated in those countries that implemented routine $\mathrm{HCV}$ testing of donors with second and third generation enzyme immunoassays, a procedure that resulted in a sharp decline in transfusionassociated HCV transmission; in other countries, receipt of blood transfusions remains an important source for infection $[3,11]$. The largest reductions in the incidence of transfusion-transmitted HCV infection have coincided 
with adoption of an all-volunteer donor system; most countries in the developing world do not screen blood donations for the presence of HCV. WHO Global Database on Blood Safety estimates that $43 \%$ of donated blood in the developing world is not screened adequately for transfusiontransmitted infections, including $\mathrm{HCV}[1,12,13]$. Although $\mathrm{HCV}$ infection represents a major public health problem in Romania, its prevalence in the general population and risk factors are largely unknown. If frequency of donation is associated with safety, it seems that repeat donors, who donate more frequently, would be better candidates for additional recruitment [14]. The HCV seropositivity among blood donors reflects both the prevalence in the general population and the performance of blood donors' selection.

The HCV frequency among blood donors in Romania has been an object for publication only in few studies.

The aim of this study was to analyze the frequency of anti-HCV antibodies in blood donors from Cluj County (Romania) and its trend, in the period 2006-2011.

\section{Patients and methods}

\section{Procedures}

In 2000, the Cluj County had 460,000 inhabitants aged 18 to 62 years old. The only regional blood transfusion centre (BTC) in the Cluj County distinguishes new donors (i.e., persons who have never donated before) from repeat donors (i.e., persons who have donated and have been tested before). Repeat donors are checked before every donation (pulse, blood pressure, haemoglobin) and complete a screening questionnaire; these are seeking to exclude the risks of acquiring transfusion-transmissible infections (TTI). If answers on the screening questionnaire raise concerns, a physician specialized in blood donors interviews the donor more extensively. After donation, the blood is tested for the presence of TTI. New donors are likewise examined physically and complete the same screening questionnaire. In contrast to repeat donors, this questionnaire is always discussed extensively by all new donors with a donor physician. They can donate only when their blood has tested negative for the presence of TTI. If reactive, these screening tests are repeated. Samples found repeatedly reactive in any screening test are submitted to confirmatory testing. Donors, who are confirmed positive for the presence of HCV or any other TTI antibodies, are invited back to the blood bank to see a donor physician. At this visit, they receive information and post-test counseling.

\section{Study population}

Subjects included new and repeat donors from Cluj County BTC confirmed positive with $\mathrm{HCV}$ antibodies in the period 2006-2011.

The method of study was descriptive and comparative in retrospective aspect.
The T-test and $\mathrm{X}^{2}$ - test were used to analyze the significance of the results.

The screening of donations was made with an ELISA test and confirmed with a RIBA test.

\section{Results}

The data collected from Cluj County BTC showed that 95,181 donations were tested in the BTC's laboratories during the 6-year period of study. The number of blood donations was stable at an average of $3.4 \%$ of inhabitants (15.864) with ages between 18 to 62 years. The majority of the donors were males $(75.2 \%), 53.1 \%$ being first time donors and $71.9 \%$ were under 40 years old.

In the Cluj County BTC database there were 242 (223 first time donors and 19 repeat donors) confirmed antiHCV-positive donations among the 95,181 donors $(50,507$ first time donors and 44,674 repeat donors) between 2006 and 2011. Table I shows the frequency rates of anti-HCV infectious disease markers that were confirmed among the first time and repeat whole-blood donors by gender and age. The overall prevalence was $0.254 \%$ (95\% CI 0.222-0.286) (Table II). The prevalence rates of anti-HCV antibodies increased with age in both genders, being higher among women, starting to decrease after the age of 51 .

\section{Discussion}

This paper describes the prevalence and incidence of HCV among allogeneic donations in a large blood centre in Romania. The study is based on exhaustive data collected using a standardized and centralized serological test. The results of this study demonstrate a high $\mathrm{HCV}$ prevalence in donations from 2006 to 2011, as compared to other countries in Europe (0.03\% in France, $0.15 \%$ in Switzerland) [15]. The overall prevalence varied significantly, ranging from $0.11 \%$ in $2009,0.16 \%$ in 2006 to $0.34 \%$ in $2011-0.36 \%$ in 2007 and 2010. This value could be explained by the high prevalence of $\mathrm{HCV}$ infection in Romanian general population [15], or by the lack of donor education, donor screening, willingness to donate and strict laboratory testing procedure. Due to this combination of measures, the blood supply is safer in developed countries [16].

Although previous research has been done on $\mathrm{HCV}$ prevalence in blood donor population from Cluj County, this analysis aimed at comparing the frequency of $\mathrm{HCV}$ transmitted infections among repeat blood donors and first time blood donors.

In this period, no overall trends were observed in the proportion of first-time donors, in the number of donors and donations per inhabitant, which led to a stable blood supply. In this study, most of the donors were first time donors. To be able to ensure an adequate supply of blood at all times, regular voluntary blood donors are the safest donors, particularly because they have been educated on how to stay healthy and lead lifestyles that are free from the risk of acquiring serious infections [17]. More than 
Table I. Frequency of HCV infection in donors, by age group and gender, 2006-2011.

\begin{tabular}{|c|c|c|c|}
\hline $\begin{array}{l}\text { Gender and } \\
\text { age (years) }\end{array}$ & $\begin{array}{c}\text { Total } \\
\text { screened }\end{array}$ & $\begin{array}{l}\text { Positivity } \\
\text { (rate, \%) }\end{array}$ & $\begin{array}{c}\text { Anti-HCV } \\
95 \% \text { CI }\end{array}$ \\
\hline \multicolumn{4}{|l|}{ Male } \\
\hline$<20$ & 6319 & 0.13 & $0.04-0.21$ \\
\hline $21-30$ & 25412 & 0.18 & $0.13-0.23$ \\
\hline $31-40$ & 20215 & 0.31 & $0.23-0.39$ \\
\hline $41-50$ & 13271 & 0.37 & $0.26-0.47$ \\
\hline $51-60$ & 6317 & 0.17 & $0.07-0.27$ \\
\hline Total & 71534 & 0.25 & $0.21-0.28$ \\
\hline \multicolumn{4}{|l|}{ Female } \\
\hline$<\mathbf{2 0}$ & 2652 & 0.11 & $0.00-0.24$ \\
\hline 21-30 & 8209 & 0.12 & $0.04-0.19$ \\
\hline $31-40$ & 5589 & 0.32 & $0.17-0.47$ \\
\hline $41-50$ & 4692 & 0.49 & $0.29-0.69$ \\
\hline $51-60$ & 2505 & 0.40 & $0.15-0.64$ \\
\hline Total & 23647 & 0.27 & $0.20-0.33$ \\
\hline \multicolumn{4}{|l|}{$\begin{array}{l}\text { Both male } \\
\text { and female }\end{array}$} \\
\hline$<20$ & 8971 & 0.12 & $0.05-0.19$ \\
\hline $21-30$ & 33621 & 0.17 & $0.12-0.21$ \\
\hline $31-40$ & 25804 & 0.31 & $0.24-0.38$ \\
\hline $41-50$ & 17963 & 0.40 & $0.30-0.49$ \\
\hline $51-60$ & 8822 & 0.24 & $0.13-0.33$ \\
\hline Total & 95181 & 0.25 & $0.22-0.28$ \\
\hline
\end{tabular}

$2 / 3$ of the donors were under 40 years of age. Particular attention should be given to youth donor retention strategies as they form the basis of a stable pool of blood donors for the future [17]. The ratio of first time donors to the total number of donors in general reflects the annual donor recruitment or, more generally, the turn-over rate in the donor base [10]. The majority of the confirmed HCV infections were found among new donors. This is not surprising, given the exposure of repeat donors to multiple selection procedures; the results are consistent with those reported in other studies in Europe. A higher proportion of first time donors was observed in Cluj County (53.1\%), as compared to France (22\%) [18] or Europe (19\%) [19]. This point should be highlighted, because a higher incidence of viral infections has been reported among first time donors as compared to repeat donors, leading to a higher risk of undetected positive viraemia and finally to more risky blood products $[10,14]$. A better quality of screening could also be taken into account too.

The frequency of "confirmed positive" donors among all first time donors tested yields the "prevalence" of an infectious diseases markers (IDM) among first time donors. This reflects the characteristics of the population from which first time donors are recruited. At the same time, we cannot ignore that the "first time donors" are already a selected healthy population and, therefore, the prevalence of infectious disease (IDM) in the general population may be different.

The frequency of "confirmed positive" donors among all repeat and regular donors tested yields the "incidence" of IDM among repeat and regular donors (i.e. those donors who had previously been tested, were found to be negative, and were allowed to donate again). This "incidence" accounts for the frequency with which repeat and regular donors acquire a new infection [10].

Our study could have some limitations. Firstly, this is a retrospective study and all biases of a retrospective study may interfere with our results. Secondly, the study is limited by the fact that no information on risk behaviors was collected for the entire donor population. Therefore, we cannot conclude whether infected donors have different frequencies of risk factors than donors who tested negative for the HCV infection. Nonetheless, the literature indicates that donor selection is effective in lowering the prevalence of transfusion transmissible diseases in the donor population [20].

In our data, women accounted for only $24.8 \%$ of the donors; this is a very low percentage if compared to the $0.98 \mathrm{M} / \mathrm{W}$ gender ratio in France in 2010. This under-

Table II. Positivity rates for anti-HCV in donations in Cluj County, 2006-2011.

\begin{tabular}{lccccccc}
\hline \multirow{2}{*}{ Year } & \multirow{2}{*}{$\begin{array}{c}\text { Total } \\
\text { screened }\end{array}$} & \multicolumn{7}{c}{ Positive rate (\%) } & \multicolumn{3}{c}{ 95\% CI } \\
\cline { 3 - 8 } & & Total & FTD & HD & Total & FTD & HD \\
\hline $\mathbf{2 0 0 6}$ & 16248 & 0.16 & 0.33 & 0.00 & $0.10-0.22$ & $0.20-0.45$ & $0.00-0.00$ \\
$\mathbf{2 0 0 7}$ & 15530 & 0.36 & 0.71 & 0.00 & $0.26-0.45$ & $0.52-0.90$ & $0.00-0.00$ \\
$\mathbf{2 0 0 8}$ & 15598 & 0.21 & 0.48 & 0.15 & $0.13-0.27$ & $0.31-0.66$ & $0.00-0.04$ \\
$\mathbf{2 0 0 9}$ & 15663 & 0.11 & 0.20 & 0.00 & $0.05-0.16$ & $0.10-0.29$ & $0.00-0.00$ \\
$\mathbf{2 0 1 0}$ & 16326 & 0.36 & 0.51 & 1.51 & $0.26-0.44$ & $0.37-0.66$ & $0.06-0.24$ \\
$\mathbf{2 0 1 1}$ & 15816 & 0.34 & 0.56 & 0.91 & $0.24-0.42$ & $0.40-0.72$ & $0.02-0.15$ \\
Total & 95181 & 0.25 & 0.44 & 0.43 & $0.22-0.28$ & $0.38-0.50$ & $0.02-0.06$ \\
\hline
\end{tabular}


representation of women remains unclear. A higher deferral rate and a lower return rate were reported in women less than 45 years old in Norway due to pregnancy and lactation [19]. At the same time, in our study the proportion of first time donors with the higher HCV seroprevalence was among women, a result consistent with the observed trend of HCV seroprevalence in the general population. This result may be attributed to the excessive nosocomial risk for the female gender due to illegal abortion during the communist period [21].

\section{Conclusion}

A high prevalence of $\mathrm{HCV}$ infection among first time blood donors is found in Cluj County, an infection that might be a potential threat to blood safety. The prevalence remains constantly high among first-time blood donors. Control and prevention of $\mathrm{HCV}$ infection remains an important public health problem. Blood donors must be screened appropriately. Therefore, control of $\mathrm{HCV}$ transmission requires a continuous monitoring and surveillance for prevention. The different frequencies of risk factors between infected donors and donors who tested negative for the $\mathrm{HCV}$ infection might be a topic of high importance for future epidemiological studies. Based on conclusions of such studies, more efficient attempts to reduce the donor-positive rates to the barest minimum to prevent infectious donations entering the blood supply could be foreseen.

\section{Acknowledgement}

The authors would like to give thanks to the personnel of the Blood Transfusion Centre from ClujNapoca, who allowed us access to the Centre's data, especially Dr. Gorgan Iuliana, as well as POSDRU for financial support.

\section{References}

1. Lavanchy D. The global burden of hepatitis C. Liver Int. 2009;29:74-81.

2. Muhlberger N, Schwarzer R, Lettmeier B, Sroczynski G, Zeuzem S, Siebert U. HCV-related burden of disease in Europe: a systematic assessment of incidence, prevalence, morbidity, and mortality. BMC Public Health. 2009;9:34. doi:10.1186/14712458-9-34

3. Kamal SM. Acute hepatitis C: a systematic review. Am J Gastroenterol. 2008;103(5):1283-1297.

4. Zein NN. The epidemiology and natural history of hepatitis $\mathrm{C}$ virus infection. Cleveland Clinic Journal of Medicine. 2003;70:S2-6.

5. WHO. Global policy report on the prevention and control of viral hepatitis in WHO Member States. 2013. Available from: http://apps. who.int/iris/bitstream/10665/85397/1/9789241564632_eng.pdf.

6. ECDC. Surveillance and prevention of hepatitis B and C in
Europe. European Centre for Disease Prevention and Control 2010; Stockholm: ECDC; 2010.

7. Rantala M, van de Laar MJ. Surveillance and epidemiology of hepatitis $\mathrm{B}$ and $\mathrm{C}$ in Europe - a review. Eurosurveillance [Internet]. 2008:[13(21):pii=18880. p.]. Available from: http:// www.eurosurveillance.org/ViewArticle.aspx?ArticleId=18880.

8. Marcellin P. Hepatitis B and hepatitis C in 2009. Liver Int. 2009;29 Suppl 1:1-8.

9. ECDC. Hepatitis B and C in the EU neighbourhood: prevalence, burden of disease and screening policies. European Centre for Disease Prevention and Control Stockholm: 2010. 2010.

10. Van der Poel CL, Janssen MP, Behr Gross ME. The Collection, Testing and Use of Blood and Blood Components in Europe, 2008 Report. 2011. Epub Department of Biological Standardization, OMCL Network \& HealthCare, European Directorate for the Quality of Medicines and Healthcare (EDQM), Council of Europe, May 2011.

11. Alter MJ. Epidemiology of hepatitis C virus infection. World J Gastroenterol. 2007; 13(17):2436-2441. Epub 2007/06/07.

12. Shepard CW, Finelli L, Alter MJ. Global epidemiology of hepatitis C virus infection. Lancet Infect Dis. 2005;5(9):558-567. 13. Kew M, François G, Lavanchy D, Margolis H, Van Damme $\mathrm{P}$, Grob P, et al. Prevention of hepatitis $\mathrm{C}$ virus infection. J Viral Hepat. 2004;11(3):198-205.

14. Schreiber GB, Glynn SA, Busch MP, Sharma UK, Wright $\mathrm{DJ}$, Kleinman $\mathrm{SH}$, et all. Incidence rates of viral infections among repeat donors:are frequent donors safer? Transfusion. 2001;41(6):730-735.

15. Brumboiu IM, Czernichow P, Hatu G, Gorgan IN, Hosu O, Bocsan IS. The seroprevalence of hepatitis $C$ virus infection among blood donors from the North West region of Romania. Rev Med Chir Soc Med Nat Iasi. 2013;117(2):465-475. Epub 2013/12/18.

16. Ji ZH, Li CY, Lv YG, Cao W, Chen YZ, Chen XP, et al. The prevalence and trends of transfusion-transmissible infectious pathogens among first-time, voluntary blood donors in Xi'an, China between 1999 and 2009. Int J Infect Dis. 2013;17(4):e259262.

17. WHO. The global need for safe blood. 200. Available from: http://www.who.int/worldblooddonorday/campaignkit/WBDD_ GlobalNeed_English.pdf.

18. Institut de Veille Sanitaire. Surveillance épidémiologique des donneurs de sang en France 1992 - 2010. Available from http:// wwwinvssantefr/surveillance/donneurs_sang/Surveillance $\% 20$ donneurs\%201992-2010\%20pour\%201e\%20site\%20InVSPPT

19. Hatu G, Brumboiu MI, Czernichow P, Bocsan IS. The risk for hepatitis $\mathrm{C}$ infection in blood donors in Cluj County, Romania. Transfusion clinique et biologique : journal de la Societe francaise de transfusion sanguine. 2014;21(2):94-97.

20. Hatu G, Brumboiu MI, Gorgan IN, Bocsan IS. Romanian blood donors screening: is it really necessary and/or mandatory? Revista medico-chirurgicala a Societatii de Medici si Naturalisti din Iasi. 2013;117(3):741-746.

21. Gheorghe L, Csiki IE, Iacob S, Gheorghe C, Smira G, Regep $\mathrm{L}$. The prevalence and risk factors of hepatitis $\mathrm{C}$ virus infection in adult population in Romania: a nationwide survey 2006 - 2008. J Gastrointestin Liver Dis. 2010;19(4):373-379. 